\title{
RAPPORT OVER HET EILAND BILLITON
}

DOOR

\section{J. I. VAN SEVENHOVEN.}

Bij besluit van Z. Exc. den Gouverneur-Generaal in rade van 24. Julij 1821, no. 1, was bepaald, dat het eiland Billiton in bezit zoude worden genomen tot bevestiging der souvereiniteitsregten, aan Z. M. den Koning bij de Londensche conventie van 13 Augustus 1814 afgestaan, en tot beteugeling der zeerooverijen, die van daaruit werden gepleegd. Deze inbezitneming geschiedde met goed gevolg, een etablissement werd opgerigt en daarover een civiel en militair kommandant benoemd, ondergeschikt aan den resident van Banka. Daar de rapporten van Billiton geen licht genoeg over den waren stand van zaken gaven, behaagde het den Gouverneur-Generaal, mij te gelasten, dat ik, alvorens naar Palembang terug te keeren, het eiland zoude bezoeken, nadat ik den toestand aldaar had leeren kennen, den civielen en militairen kommandant de noodige inlichtingen zoude geven en verder na overleg met den kolonel en resident van Banka 1 zoodanige bepalingen zoude maken, als dienstig werden geacht, om de belangen van het gouvernement te bevorderen.

Ingevolge dezen last begaf ik mij op Donderdag den 10den Julij 1823 aan boord van het partikuliere schip Ennore Transil, varende onder Nederlandsche vlag en gevoerd door den schipper W. Lindesay. In mijn gevolg bevonden zich de ambtenaren M.

1 Alfred Désiré Grégoire de la Fontaine, chef van den staf der expeditie naar Palembang in 1821, werd in hetzelfde jaar tot resident van Banka benoemd, welke betrekking hij tot zijn overlijden in 1825 bekleedde. 
Francis en A. Spruit, benevens de Palembangsche Pangeran Adipati Njeira de Ningrat en vier radeens. Het schip was bevracht met provisiën, geld en geschut voor Billiton. Des avonds tè zes uur verlieten wij de reede van Batavia, en zeilden met een matige koelte, nu en dan afgewisseld door buijen, langzaam voort. Maandag den 14den Julij verkenden wij in den namiddag het Shoalwaterisle of Ondiepwatereiland, dat wij met een fellen stroom, die om de oost liep, passeerden; het lood wees een ongelijke diepte van 15 tot 7 vadem aan. Den volgenden dag voeren wij door Straat Macclesfield. Men kan zich geen aangenamer gezigt op zee voorstellen, dan deze straat oplevert, vooral, als men zulk helder en goed weder treft, als wij genoten; men zeilt als het ware in eene groote kom, die omringd is van kleine en groote eilanden, wier verschillende vormen benevens hunne berg- of heuvelachtige oppervlakte de fraaiste figuren vertoonen en, daar men zeer nabij de meeste vaart, gedurig nieuwe gezigten opleveren. Deze verrassingen vergoedden mij het onaangename en ongeruste van het scheepsleven. In den namiddag ontdekten wij behalve eenige kleine vaartuigen een schip, dat ten anker lag; kort daarna kwam de luitenant der koloniale marine Verveer bij ons aan boord, die ons berigtte, dat het schip de korvet Koerier was. Ik zond derwaarts de depeches voor den kommandant den $1^{n}$ luitenant Stolze en wij zeilden verdèr, van zins bij de korvet te ankeren. Intusschen had de heer Verveer den last gekregen, zijne commissie, het opnemen der kust te vervolgen, waartoe hịj een kanonneerboot en eenige kleine vaartuigen bezigde. Daar de wind hard opstak en de lucht betrok, was het niet mogelijk, in de nabijheid der korvet te komen; wij werden door wind en stroom geheel uit den koers gedreven, zoodat het schip voortzeilde, niet zonder gevaar van op de klippen te stooten. Den 16 den Julij zagen wij bij het aanbreken van den dag, dat wij de korvet ver voorbij waren en aan alle kanten tusschen klippen lagen. Door het gemis eener goede kaart van dit gevaarlijke vaarwater stootten wij op een klip; gelukkig waaide het niet hard, en kwamen wij door het goed beleid van onzen schipper weder vlot, hetgeen een groot geluk was, omdat kort daarna een zware bui ons schip teisterde. Nadat wij die ontkomen waren, vond de schipper het raadzaam, te ankerẹ, dewijl dit vaarwater als met klippen bezaaid is. Zoo waren wij den 17 den Julij, bijna vijf uur uit den wal van Billiton, op de plaats onzer bestemming. Ik 
zond toen den ambtenaar Francis aan land, om den civielen en militairen kommandant mijne, aankomst te berigten.

Vrijdag den 18den Julij kwamen bij mij aan boord de Panembahan Sarief Mohamed, de inlandsche majoor Tompel, Pangeran Said Akil en Pangeran Soera di Laga. Te 9 uur des voormiddags vertrok $i k$ met hen van boord en stapte te twee uur aan land aan den mond der rivier Tjoeroetjoep. Hier bezigtigde ik deze schoone situatie, een goede gelegenheid voor een etablissement, waarvan ik hieronder eene opgave zal doen, terwijl ik ook nog den beruchten zeeroover Radeen Alie, met zijne familie en eenige onderhoorigen ontmoette. Na een uur toevens roeide $\mathrm{ik}$ de Tjoeroetjoep verder op en werd aangenaam verrast door deze fraaije rivier. Het scheen mij, alsof ik aan alle kanten in spiegels zag, en dat alles zich op het verrukkelijkst terugkaatste en een helder groen vertoonde, waarin ik als besloten scheen, terwijl evenwel het schuitje voortging. Eindelijk ontdekte ik dat het kristalhelder water deze misleiding te weeg bragt; de geheele rivier was een spiegel, waarin de boomen en planten der beide oevers zoodanig teruggekaatst werden, dat zij geheel groen geleek; terwijl eerst bij eene naauwkeurige beschouwing de afzonderlijke voorwerpen zich afscheidden. Naarmate de zon daalde, werd de schaduw langer en bragt de zeldzaamste beelden op het water te voorschijn. Eindelijk bereikte ik eerst des avonds te zes uur, nadat ik acht uur in een klein scheepje had doorgebrägt, Tandjong Semba, het verblijf van den kommandant, die mij met blijdschap ontving.

Hiermede breek ik dit dagverhaal af en zal, hetgeen verder in dit rapport moet worden behandeld, in deze orde bespreken :

10. den staat, waarin ik de zaken op Billiton heb gevonden;

2o. de gesteldheid van het eiland, zijne voortbrengselen en bewoners;

3o. mijne verrigtingen op Billiton en mijne voorstellen aan den kolonel en resident van Banka, omtrent hetgeen naar mijn inzien noodzakelijk moet worden gedaan;

40. de maatregelen, die volgens mijne geringe kennis ten aanzien van Billiton moeten genomen worden om het op de minst kostbare wijze dienstbaar te maken aan de belangen van het Nederlandsche gouvernement. 
Alvorens tot het eerste punt over te gaan, acht ik het noodig, iets te zeggen over de karakters der personen, die in de behandeling der zaken te Billiton een hoofdrol hebben gespeeld, opdat men te beter versta, hoe het mogelijk was, dat de zaken daar in zulk een verwarden toestand zijn gekomen, als ik dien gevonden heb.

De eerste persoon, die hier in aanmerking komt, is de civiele en militaire kommaudant. Het is inderdaad moeijelijk eene juiste beschrijving van zijn karakter te geven, omdat braafheid met onverstand en laatdunkenheid met goeden wil zich bij afwisseling in zijne handelingen vertoonen. Nimmer ontmoette $\mathrm{ik}$ iemand, die zooveel verbeelding van zijue talenten had als onze kommandant. $\mathrm{H}_{1 j}$ meent dat alles, wat in zijne gedachten komt, en dat alles. wat hij gedaan heeft, het verstandigste en het beste is, wat ooit een mensch zou kunnen denken of verrigten; ook houdt hij zich voor een bekwaam officier der genie, en doorkneed in alle vakken van administratie, policie, bestuur enz., enz. Vooral beweert hij, dat hij met inlanders kan omgaan, dat hij hunne taal, zeden en gewoonten kent, dat hij de Nederduitsche taal volkomen magtig is, hoezeer het tegendeel uit alles blijkt. Aan dezen zotten eigenwaan wijt ik alleen al de verkeerdheden, die hij gedaan heeft. Dezen eigenwaan heeft hij verkregen door zijne onbeperkte eerzucht, dewijl hij zich onophoudelijk geoefend heeft in vakken van wetenschap, waarvoor zijn natuurlijk verstand geen vatbaärheid bezat, daarvan een en ander zeer oppervlakkig weet en nu meent, dat hij alles kent en van alle zaken boven andereu verstand heeft. Hij is inderdaad te beklagen; men gevoelt innig medelijden met iemand, die zoo veel inspanning doet, om te leeren, en daarbij het beperkste verstand heeft, dat men zich kan voorstellen. Ik ben meermalen op de gedachte gekomen, of zijne overgroote zucht, om meer te zijn dan zijne intellectuele vermogens gedoogen, niet zijn verstand gekrenkt heeft. Althans ik heb verschillende zijner verklaringen niet anders kunnen uitleggen. Maar nog meer beklagen wij dezen man, als wij zien, hoe hij met het ernstigste verlangen om nuttig te zijn voor de taak, die hem is opgedragen, de grootste verkeerdheden begaat, terwijl deze verkeerdheden alleen geschied zijn, omdat zijn eigenzinnigheid niet toeliet, den raad van anderen in te winnen of te volgen en omdat hij alleen de man wil zijn, die alles doet en alles doen kan, en zich verbeeldt dat hy minder eer zal inoogsten, wanneer anderen 
iets doen, zelfs zij, die hem tot hulp zijn toegevoegd. Hieraan en aan zijn streven, om 's lands belang te behartigen, moet meu het toeschrijven, dat hij niet alleen in persoon de geldkas behandelt en van gemeene inlanders den verkoopprijs voor een halven pikol rijst of zout ontvangt, maar zelfs uit de magazijnen de kleinste verstrekkingen doet en evenals een winkelier met de koopers over - het gewigt twist, terwijl hij, door al zijn tijd aan zulke niets beduidende verrigtingen te verkwisten, zijn administratie in deerlijke verwarring bragt. In een woord, ik beschouw hem als een man ten eenemale ongeschikt voor zijn post, niet omdat hij geen braafheid en ijver genoeg zoude bezitten, maar omdat hij hoegenaamd niet in staat is, op zich zelf te staan en te handelen. Lan alle kanten heeft men hem misleid en zijn gering doorzigt, zijne verbeelding van zich zelf, zijne zucht om te voldoen en eer te behalen, nebben hem telkens doen struikelen. Bịj het minste uitzigt, dat men hem gaf, zag hij dadelijk de zaak reeds tot stand gebragt. Zoo meende hij bij voorbeeld het gouvernement een schat aan te brengen uit de tin- en goudmijnen van Billiton; hij beschouwde zich als de eenige man, die deze bronnen had kumnen ontdekken, en is reeds gelukkig in den roem, dien hij daardoor zal verwerven, terwijl de goede man met geen mogelijkheid de middelen kan verkrijgen, om eene noemenswaardige hoeveelheid dezer metalen te produceren, en het goud althans nog lang in den schoot der aarde zal blijven rusten, voordat men de enorme kosten zal wagen, die tot het zoeken vereischt worden.

De tweede persoon te Billiton is de Pauembahan Sarief Mohamed. $\mathrm{Hij}_{\mathrm{ij}}$ is een Palembangsche prins, die vele belangrijke commissiën voor de vorsten van Palembang heeft volbragt en die behalve zijn fijn natuurlijk oordeel veel kennis bezit. Even ongeschikt als de civiele en militaire kommandant is, even geschikt was hij, om Billiton onder het Nederlandsch gezag te brengen, zonder eenig geweld te gebruiken, maar op eene verstandige inlandsche wijs. Zoo hij met een ander had te doen gehad, zoude hij zeker de inzigten van het gouvernement hebben volbragt. Hoe volkomen ik hem ook beschouw ten opzigte van zijne ondervinding en vernuft, evenzeer vol gebreken is zijn hart. Evenals de meeste Palembangsche grooten is hij trotsch, verwaand, hoogmoedig en zeer gesteld op eer en eerbewijzen. Te veel geprezen en vertrouwd, heeft hij daarvan, zooals alle Palembangsche zullen doen, misbruik gemaakt en was dus alleronaangenaamst 
Algemeen is mij opgegeven, dat hij, hoezeer hij veel geld gewonnen heeft, dit weder heeft uitgegeven aan armen -van zijne familie en aan anderen, die zijn gevolg of aanhang wilden uitmaken. $\mathrm{Nu}$ is het gemakkelijk te begrijpen, dat twee karakters, zooals die van den kommandant en den Panembahan, beiden even jaloersch op eer en aanzien, niet met elkander konden harmonieeren, hetgeen de nadeeligste gevolgen heeft gehad.

De derde persoon is zeker inlandsch kind Wetering Buis ', die als klerk te Muntok tot niets anders kon worden gebruikt, dan tot het invullen van passen voor reizigers. Deze heeft al de gebreken eigen aan inlandsche kinderen. Hij is hoogst nederig tegen den kommandant, vleit hem en heeft door allerlei verzinselen tegen den Panembahan zijn vertrouwen gewonnen en de oneenigheid, die tusschen deze twee bestaat, meer en meer vergroot. Hij is trotsch tegen de inlanders en leeft als een groot heer; hij is te dom, om de oogmerken van het gouvernement met Billiton te kunnen begrijpen en heeft aan hoofden en ingezetenen gedachten omtrent deze oogmerken ingeprént, die den nadeeligsten indruk hebben gemaakt. Hij kan den kommandant in niets dienen, want hoewel hij zeer goed Maleisch verstaat, kent hij te weinig Hollandsch, om den kommandant, die dit ook maar half verstaat, over te brengen wat hem gezegd wordt. Bij het verdriet, dat ik te Billiton had, moest ik meermalen lagchen, als ik onzen kommandant, die volstrekt niet wil, dat Wetering Buis Maleisch tegen hem spreekt, met dezen een Hollandsch gesprek hoorde voeren, waarin zij elkander niet verstonden en als ik hen dan soms teregt hielp, was onze kommandant ịn het geheel niet in zijn humeur, dat ik twijfelde aan zijn volkomen kennis onzer taal. Hierbij kan ik nog mededeelen, als eene bijdrage, hoe moeilijk de kommandant zich de zaken maakt, dat hij alles eerst in het Fransch en daarna met behulp van een woordenboek in het Hollandsch schrijft. Tk heb hem aangetoond, dat hij geheel iets anders had terneergesteld dan hetgeen hij, zooals mij uit de zaak bleek, had willen zeggen en heb hem geraden, dat hij zijn luitenant van Cattenburg, een jong en fatsoenlijk officier, die gaarne in dit

1 Waarschijnlijk Willem van de Wetering Euys, die benevens eenige inlandsche vrouwen in 1811 aan den moord der Nederlandsche bezetting te Palembang ontsnapte. Zie .J. C Baud, Palembang in 1811 en 1812, Bijdragen, D. I, bl. 15. 
afgelegen verblijf iets te doen zoude hebben, op zoude dragen, zijn brieven en rapporten in het Hollandsch te vertalen, maar hij zeide, dat hij beter Hollandsch verstond dan deze. Hiertegen viel dus niet te redeneren; vooral niet, daar ik hem altijd verzocht, om met mij Fransch te spreken, omdat ik hem anders volstrekt niet begrijpen kon. Men zal uit dit weinige ontwaren, dat Wetering Buis meer nadeelig dan nuttig te Billiton is.

De vierde persoon is de inlandsche majoor Tompel, een oud man, die indertijd verscheiden commissiën voor het gouvernement goed heeft uitgevoerd en toen van nut is geweest, maar die oud is geworden en nu in den verwarden toestand van Billiton op zijne wijze eene rol speelt. Onzeker, wat er van deu Panembahan zal worden, makt hij zoowel dezen als den kommandant komplimenten en tracht' altijd bij beiden de goede man te zijn, om in het eind niets te verliezen. Zelf wenscht hij echter het meeste gezag.

De vijfde persoon is de Dipati van het elland Billiton, die bijzonder de aandacht verdient. Hij is een man van 21 of 25 jaar, de zoon van den voormaligen Dipati, die volgens bekomen informatie gedurende het Engelsch bestuur te Banka door Radja Akil op eene verradelijke wijze zoude zijn vermoord. De Dipati wordt gehouden voor het hoofd van Billiton (hieronder zal men zien, hoe men dit moet verstaan). Toen de Panembahan het eiland in bezit nam, nam hij dit hoofd, die zijn vader niet wettig was opgevolgd, als zoon aan, en gaf hem den titel van zijn vader. Dezen Dipati mag men veilig een der slimste inlanders noemen, maar daarbij behebt met alle oudeugden; gemakkelijk, trotsch, overgegeven aan het spel en de vrouwen, verkwist hij ziju tijd door van het eene inlandsch vermaak tot het andere over te gaan, terwijl hem niets te heilig is, om aan deze levenswijze voedsel te geven. Toen de Panembahan hem tot Dipati verheven had en van hem ondergeschiktheid en orde in zijne handelingen verlangde, was hem dit lastig en onaangenaam. Spoedig zag zijn slimheid, hoe het tusschen den kommandant en den Panembahan stond. $\mathrm{Nu}$ vleide hij den eerste en onttrok zich aan den laatste; hij misleidde onzen kommandant op de schandelijkste manier, die, niet opgewassen tegen zijn listen, meende, als hij met het hoofd van Billiton wel was, den Panembahan te kumnen ontberen. In zijn eigenwaan verbeeldde hij zich, door zijn behandeling en beleid de genegenheid van het hoofd gewonnen 
te hebben, en in de gedachte, daardoor zeer bevorderlijk te zijn aan zijnen last, sloeg hij de waarschuwingen van den Panembahan in den wind en heef́t hị zich door dezen slimmen en slechten Dipati laten bedriegen.

Eindelijk bevinden zich nog te Billiton Pangeran . Said Akil, Radeen Tonko T'ahat ${ }^{1}$ en andere grooten van Linga en Trengano met hun gevolg, die bij den Panembahan behooren en allen nut zouden hebben moeten bewijzen aan de oogmerken van het gouvernement, maar die, zooals dit an inlanders eigen is, de verwarde huishouding van den kommandant ziende, elk op zijne wijze, daarvan voordeel trachten te trekken. Sommigen van hen doen zich voor, alsof zij spionuen zijn van den Panembahan, anderen van den Dipati en elk brengt zulke berigten aan den kommandant, als hij meent, dat aan zijn eigen zaak of aan die, welke hij dient, nuttig is. Onze kommandant verkrijgt dus allerlei berigten, die hem van de eene gedachte tot de andere brengen; nu eens vreest hij, dat men hem zal afloopen, dan weder ontvangt hịi goede berigten over de Billitonneezen, zoodat de verwarring, waarin hij dikwijls gebragt wordt, hem, die niemand raadpleegt, het hoofd doet duizelen. Om zich van spionnen te bedienen tegen zulke kerels, als den kommandant oinringeu, moet men eene buitengewone schranderheid bezitten en het is slechts weinigen gegeven, nut van spionnen te trekken en voor te komen, dat zij ons zelve bespionneeren en bedriegen. Mij voorstellende, welke angstige uren deze slimme kerels den kommandant veroorzaakt hebben, heb ik alles gedaan, wat ik kon, om hem te bewegen, toch geen spionnen te gebruiken, doch toen hij mịj betuigde, dat men zonder spionnen niet kon regeren, heb ik hem bijna gebeden, zich toch te ontdoen van deze ellendigen, die zijn toestand zoo zeer onaangenaam maakten, maar vruchteloos.

Na deze gebrekkige opgaven over de karakters der personen, die te Billiton een hoofdrol spelen, zal ik overgaan tot den staat, waarin ik de zaken aldaar gevonden heb.

Hetgeen het eerst mijne aandacht trok, was de plaats, waar

1 In de derde bij deze memorie behoorende bijlage zijn dit twee personen Radeen Tahat en Tonko Soe. 
de kommandant had goed gevonden eene sterkte van paalwerk op te rigten. Dit werk, een vierkant van 160 voet met twee halve cirkels voor de verdediging, stond in het bosch, dat rondom gekapt was, eenige voeten van den oever der rivier en drie uur varens van den mond. Men kan zich geen onaangenamer verblijf voorstellen. De rivier is niet breed en de overkant evenzeer met digt bosch begroeid als de omtrek van het fort. Men heeft dus geen uitzigt dan op wild bosch en kan geen andere wandeling doen dan op het kleine vierkante plein in deze sterkte. Een andere ongelegenheid is, dat de rivier bij laag water zelfs niet met sloepen kan worden bevaren; als het noodig ware, de sterkte te outruimen, zoude dit niet eens ten allen tijde kunnen geschieden. Ook het ongemak, leeftogt en goederen naar de sterkte te vervoeren, is zeer groot, daar de kleine vaartuigen ten minste 24 uur noodig hebben, om naar. boven te varen, als het getij dit getoogt, en anders in den mond der rivier moeten blijven wachten. Indien deze sterkte ongelukkig overmeesterd mogt worden, blijft er geen hoop op redding voor een enkel man der bézetting, daar men dan noch te water noch over land zoude kunnen terugtrekken.

Toen ik den kommandant naar de reden vroeg, waarom hij eene plaats, die zoo ongelegen was en bij zoo vele nadeelen geen enkel voordeel aanbood, had uitgekozen, antwoordde hij mij : dat hij gemeend had, dieper landwaarts gemakkelijker met de ingezetenen in aauraking te komen; dat de Dipati hem deze plaats had aangewezen en beloofd had, in de nabijheid daarvan een dorp te zullen oprigten van twee honderd huizen; dat hij zoo ver van den mond der rivier veiliger was tegen de zeeroovers; eindelijk dat de gelegenheid aan den mond der rivier hem als zeer ongezond was opgegeven. Hij erkende echter, dat hij de ongelegenheid en al, hetgeen tegen de tegenwoordige ligging te Tandjong-Semba te zeggen was, reeds in ruime mate had ondervonden, dat de Dipati hem had misleid door de belofte, een groot dorp in de nabijheid aan te leggen, en dat hij ook reeds voornemens was, het fort naar TandjongGoenong aan den mond der rivier te verleggen. Volgens des kommandants eigen erkentenis zijn dus de aan dit fort besteede moeite en kosten vruchteloos aangewend, en zal men te Tandjong-Goenong weder op nieuw moeten beginnen.

Het is hier de geschikte plaats, mijne gedachten over de 
stelling te Tandjong-Goenong mede te deelen. I Dit ligt ter linkerzijde aan den mond der rivier Tjoeroetjoep, een kwartier van het zeestrand; het is een heuvel, die wel honderd voet hoog is. In den mond der rivier liggen duizende groote en kleine rivier- of klipsteenen, doch voor dezen heuvel is een kom, waar de vaartuigen, zelfs kanonneerbooten, veilig kunnen liggen, die dus, indien er een fortje of sterkte op den heuvel wordt aangelegd, beschermd kunnen worden en wederzijds bescherming kunnen geven. Het zeestrand is van zuiver zand en de rivier zoo helder, dat er zelfs geen nipah groeit. Ter zijde van den heuvel stort zich in den mond der rivier Tjoeroetjoep een klein riviertje, de Soengie Saboerie ${ }^{2}$, die altijd zoet water geeft. De grond om den heuvel schijnt zeer vruchtbaar te zijñ ; althans ik vond er mollige tuinaarde, met allerlei zwaar en ligt hout begroeid, terwijl de geheele omtrek wegens het uitzigt op de zee, waaruit zich eenige eilandjes verheffen, op den breeden mond der rivier en op den overliggenden oever, die schilderachtige heuvelen heeft, als een fraai en aangenaam oord kan beschouwd worden, waar men met genoegen zijn verblijf zal vestigen. Waarom het nu, zooals de kommandant had opgegeven, hier ongezond zou zijn, heb ik niet kunnen nagaan. Mij is integendeel verzekerd, en wel door personen, die in den omtrek wonen, dat het er niet ongezond is. Ook is mij niets voorgekomen, waarom het ongezond zoude zijn. Behalve de geschiktheid voor eene goede verdediging en de aangename en, zoo ik geloof, gezonde ligging aan den mond eener groote rivier biedt deze plaats nog andere voordeelen aan. Zoo geven de koraalriffen in zee stof om kalk te branden en de rivier klipsteenen, waarvan men kan bouwen, zooals ik gezien heb, dat men te Buitenzorg, Tandjoer en elders op Java doet. Bovendien is er in de nabijheid hout in overvloed te vinden. De gronden aan den oever der rivier en eenigzins daarvan verwijderd schijnen zeer geschikt, om in vruchtgevende velden herschapen te worden. Hierdoor zal het gemakkelijk vallen, in de nabijheid van het etablissement een of meer dorpen op te rigten, hetgeen ik als zeer noodig beschouw.

1 Het fort nabij de tegenwoordige hoofdkampong Pandang ligt op T. Goenoeng, maar volgens de kaart van den ingenieur de Groot aan de regterzijde der rivier. Natuurk. Tïjschr. III. bl. 146

${ }_{2}$ In dit riviertje werd in 1851 door de Billiton-compagnie het eerste tinerts gevonden. Tijdschr, voor Neerl. Ind. 1853, I, bl. 23. 
Te eer zál men daartoe overgaan, daar de zee veel smakekelijke en voedende visch oplevert, voorts tripang, agar-agar, en andere voordeel gevende voortbrengselen, zoodat de genen, die zich in de nabijheid van Tandjong-Goenong nederzetten, zich terstond voedsel en voordeel kunnen verschaffen, zonderdat zij, zooals te Tandjong-Semba, moeten wachten totdat de veldvruchten rijp ziju, waarvoor het bosch eerst moet worden omgekapt. Het is dan ook gebleken, dat niemand zich te Tandjong-Semba wilde nederzetten, zelfs twee of drie Chineezen van Borneo zijn spoedig weer vertrokken. Alles pleit dus ten voordeele van deze gelegenheid. De Panembahan verhaalde mij, dat hij ook voornemens was geweest, hier het etablissement aan te leggen, maar dat de kommandant zich door den Dipati had laten bepraten, het fort te Tandjong-Semba op te rigten, hetwelk hij ten sterkste had afgeraden.

De tweede zaak, waarmede ik mij bij mijne komst te Billiton moest onledig houden, was de oneenigheid tusschen den kommandant en den Panembahan. Anderhalven dag had ik reeds bij den kommandant doorgebragt en van niets anders door hem hooren spreken dan van zijne moeilijkheden met den Panembahan. Zijne voordragten waren echter zoo verward en in deze zaak zoo veel lieden betrokken, die ik te voren genoemd heb, en wier verhouding ik nog niet kende, dat het mij niet mogelijk was, iets te begrijpen van al, wat hij mij met drift verhaalde, zoodat ik telkens moest verzoeken, toch iedere omstandigheid geheel uit te vertellen. Toen ik er eindelijk zeer verdrietig onder werd, vroeg ik hem, mij punten te noemen, . waarover ik den Panembahan zou hooren. Met veel moeite kwam ik eindelijk te weten, dat de Panembahan van hem onafhankelijk. had willen zijn, dat hij aan het gouvernement meer vaartuigen en volk in rekening bragt, dan hij in dienst had, en dat hij handel had gedreven hetgeen hij volgens den kommandant niet mogt doen.

De Panembahan hierover gehoord zijnde, antwoordde mij : ik laat het aan uw eigen oordeel over, of ik met een man als de kommandant heb kunnen werken; alles wil hij beter weten; al, wat ik hem zeide, dat goed was, deed hij geheel anders, omdat hij van mij geen raad wilde aannemen. Als ik hem mijn gevoelen over het een of ander zeide, antwoordde hij mij : dat heb ik reeds voorlang geweten; ik weet alles; gij behoeft mij niet te leeren; ik ben de man, die moet weten, hoe alhier 
gehandeld moet worden; gij moet mijne orders volgen, enz. Aan dit onverstandig gedrag was het dan ook toe te schrijven, dat er niets goed verrigt kon worden en dat onze kommandant, misleid, bedrogen en geheel op den verkeerden weg gebragt, nu in de grootste verlegenheid is. Wat het beweren betrof, dat ${ }^{-}$ hij meer vaartuigen en volk in rekening zoude brengen dan hij in dienst had, was de kommandant niet bevoegd, dit te beoordeelen, daar deze alleen gekwalificeerd was, hem voorşchot te geven, maar niet, met hem te rekenen. Dit moest hij met den kolonel en resident van Banka doen, en dit had hij den kommandant gezegd, maar deze, die hem haatte, zocht hierin nu eene beschuldiging tegen hem. Wat de zaak zelf betrof, was het onwaar, dat hij, Panembahan, groote uitgaven te Billiton had gedaan. Naderhand heb ik gezien, dat de kommandant alleen was geautoriseerd, den Panembahan voorschotten te geven. Ook in een verschil over eene som, ik meen van $f 500$ of $f 600$, overtuigde deze den kommandant, dat hij dit geld moest ontvangen, welke hem eerst deze som had teruggevorderd, nadat hij die reeds had uitbetaald en ze hem nu wederom teruggaf, zoodat het mij voorkwam, dat de kommandant wat al te zeer in drift had gehandeld. Op de beschuldiging, dat hịj handel zoude gedreven hebben, antwoordde de Panembahan, dat personen van zijne familie te Billiton waren komen handelen, en dat hij, in plaats van te meenen dat dit kwaad was, zulks als zeer goed had beschouwd en aangemoedigd.

Het is geenszins te verwonderen, dat twee personen in deze verhouding en van humne geaardheid en karakter zeer tegen elkander zijn geweest en elkander niet konden verdragen. Ik beschouw hen beide schuldig en kan gemakkelijk nagaan, dat zij elkander in de weg waren. Beide wilden op Billiton regeren, en beide trachtten elkander dit te beletten of moeijelijk te maken. Was de kommandant verstandiger geweest, dan zoude hị van de kennis, het vernuft en den invloed van den Panembahan gebruik hebben gemaakt ten voordeele van de taak, waartoe hij geroepen was, maar hij kon niet dulden, dat de Panembahan zou worden beschouwd als de man, door wien hij had gewerkt, en nu benam hij hem elk gezag en invloed, door steeds andere bevelen te geven. De Panembahan, hierover gebelgd, werkte nu den kommandant tegen. Jammer maar, dat de belangen van het gouvernement hieronder zooveel geleden 
hebben, waardoor het nog lang zal duren, voordat er weder eene goede orde te Billiton is gevestigd.

Behalve deze oneenigheden, die zoo nadeelig zijn geweest, vernam ik nu ook, op welke wijs de Dipati of het zoogenaamde hoofd van Billiton den kommandant had bedrogen. Deze had hem, om hem te vriend te houden, omtrent twee duizend gulden aan geld, rijst en zout op krediet gegeven, waarvoor de Dipati alles beloofde, maar niets is nagekomen. Daarbij voert deze nog een insolenten toon en doet, wat hij goedvindt. Op ver: zoek van den kommandant onderhield ik hem over de nako-s ming zijner belofte om een dorp van twee honderd huizen in de nabijheid van het fort op te rigten. In tegenwoordigheid van den kommandant zeide hij, dat hij dit nimmer had beloofd, dat hij gezegd had, over twee honderd menschen gezag te voeren en dat het zijn schuld niet was, als de kommandant geen Maleisch genoeg kende, om hem te verstaan. Ik vroeg hem verder, wat hij dan met het ontvangen geld, rijst en zout had gedaan, en op welke wijze hij zijne schuld wilde vereffenen. Hierop antwoordde hij, dat de kommandant hem had gezegd, dat het gouvernement de inwoners van Billiton zoude helpen aan al, wat zij noodig hadden; dat hij de voorgeschoten gelden als een blijk daarvan beschouwd had; dat hij aan elk der vier overige hoofden van Billiton honderd gulden had gegeven en van het overige geld vrolijk had geleefd en gespeeld; dat nu alles verteerd was, en dat hij, zoo hij het terug moest geven, daaraan zoude denken, maar volstrekt niet kon bepalen, wanneer of op welke wijze de aflossing zoude geschieden. De onbeschofte toon, waarop hij dit alles voordroeg, ergerde mij zeer, en als er een ander man kommandant was geweest, zoude ik den Dipati geleerd hebben, dat wij zulke impertinenties niet straffeloos gedoogen.

$\mathrm{Nu}$ vreesde ik, de verwarring slechts te zullen vergrooten, en bedroefde mij, dat het gedrag van den kommandant aanleiding had gegeven, dat hij volstrekt niet geacht is. Hoe kon dit ook anders, daar hij nu eens als winkelier met den gemeenen man twist over het ruilen van rijst en zout voor geld en tripang (welke laatste men hem zelfs in bedorven staat leverde), dan weder den kommandant en chef moet vertoonen; daar hij zich van allerlei gemeene en slechte kerels alles laat wijsmaken, wat zij verkiezen, hem te vertellen, en door den een hier en door den ander ginds geleid wordt; daar hij niet de 
bekwaamheid bezit, zijne gewaarwordingen te bedwingen, als men hem iets verhaalt, terwijl eindelijk de domme en trotsche Wetering Buis de zaken nog meer verergert, door de meening van den kommandant te expliceren. Door dit alles is het dan ook gebeurd, dat de Orang-Sekah of zoogenaamde Orang-Laut, die in de nabijheid van de rivier Tjoeroetjoep op het water woonden, naar een ander gedeelte van het eiland zijn vertrokken; dat de vier mindere hoofden van het eiland zich volstrekt niet aan den kommandant laten gelegen liggen, omdat niemand een goed begrip heeft van hetgeen hij wil of van het oogmerk van het gouvernement; dat de voorgenomen ruilhandel, om de inwoners voor spijkers, tripang, agar-agar en andere voortbrengselen van het benoodigde te voorzien, volstrekt niet bestaat; dat de kommandant geen enkel man kan krijgen, om te werken, zoodat hij, toen het schip, waarmede ik gekomen was, ontladen moest worden, eene ropij daags, benevens rijst en zout moest geven aan hen, die daaraan geholpen hebben, zijnde dit volk van onderscheiden personen, die zich aan den mond der rivier hebben nedergezet. Zoo zijn wij te Billiton eigenlijk zonder eenig gezag. En geen wonder, want de kommandant bezit door zijn brouillerie met den Panembahan en door zijne vestiging in het bosch, waar hij zich onmogelijk veilig kan achten, noch magt noch vertrouwen op zijn sterkte; hij moet zich alles laten welgevallen, terwijl hij daarenboven door zijn gedrag geen achting heeft weten in te boezemen voor zijn persoon. Voegt men hier nu bij, dat zijne verantwoording van goederen en gelden in zulk een verwarden staat is, dat het mij niet mogelijk was, daaruit wijs te worden, dan zal niemand betwijfelen, dat het hoogst noodzakelijk is, den kommandant te vervangen. Ook voor hem is zijn toestand allerbeklagenswaardig, daar hij met zijn luitenant en dokter of chirurgijn, de eenige Europeanen, waarmede hij zoude kunnen omgaan, op een verwijderden voet leeft. Meermalen heb ik dan ook het innigste medelijden met hem gevoeld. Overdag is hij bezig met zijne pakhuizen en moet hij allerlei rapporten hooren, zoodat hij zijn schrijfwerk des avonds of 's nachts verrigt. Daardoor is hij dan ook zoo afgewerkt, dat hij. er werkelijk ziek van was en niet in staat, die opgaven te doen, welke ik verlangde, om een eisch voor vivres en gelden op te maken, zooals mij door de hoofddirectie van financiën was opgedragen. In weerwil van dit alles - en dit is voor hem nog een geluk - 
verbeeldt hij zich, dat hij zich zeer verdienstelijk makkt, omdat hij van den morgen tot den nacht bezig is. Ik wensch van harte, dat hij geen berisping krijgt over zijn gedrag en verrigtingen, maar dat alles verschoond wordt, dewijl het zijne schuld niet is, dat hem eene betrekking is opgedragen, waarvoor hij niet berekend was, terwijl hij nog steeds meent, zijn best gedaan te hebben, en inderdaad de beste bedoelingen heeft. Hartelijk blijde was ik dat ik, na vijf lange en verdrietige dagen bij den kommandant te hebben doorgebragt, hem vaarwel kon zeggen, zooals ik ook zeer verheugd ben, dit onaangename gedeelte van mijn rapport te hebben afgehandeld, en nu zal overgaan tot het mededeelen van eenige aanteekeningen betreffende de gesteldheid van Billiton de voortbrengselen en de bewoners van dit eiland.

Billiton ligt teu oosten van het eiland Banka op een afstand van 20 a 25 mijlen. Het heeft eene vierhoekige gedaante en wordt gerekend eene oppervlakte te beslaan van 120 vierkante geografische mijlen. Op het eiland verheffen zich verschillende bergen en heuvelen. Het is doorsneden door een aantal rivieren, waarvan de voornaamste zijn: de Blantoe, de Brang, de Kimirie, de Lingan, de Boeding, de Pandang, de Siedjoe, de Koeboe, de Badauw, de Tjoeroetjoep en de Spil, waarvoor een baai ligt, waar nog drie kleine rivieren in uitwateren. Rondom het geheele eiland liggen kleinere eilandjes en rotsen van koraalsteen. De grond van het eiland is geheel bedekt met bosschen, waarin zeer goede houtsoorten worden gevonden zooals het timbesso-, ambello-, billian-, en garoe-hout. Het hart der aarde bevat verscheiden kostbare metalen, als goud, tin en ijzer; van het laatste wordt reeds veel bewerkt, meestal tot spijkers. De grond is zeer vruchtbaar; rijst en alle andere voedingsmiddelen groeijen welig; koffij, suiker en katoen toonen, hoezeer de kultuur daarvan nog in den staat der kindschheid is, dat ook deze artikelen met voordeel zouden kunnen worden aangekweekt. In de bosschen wordt was en in sommige holen vogelnestjes gevonden. De zee levert de beste vischsoorten in overvloed, die ook gedroogd verkocht worden. Agar-agar, tripang en schildpad zijn zeer gewilde artikelen voor den handel op China; men heeft mij ook gezegd, dat er parelreven zouden zijn. Wat dus den grond en de natuurlijke voortbrengselen van Billiton 
betreflen, biedt het ruime voordeelen aan, en bevat het middelen, die niet overal in zoo ruime mate tot voeding van deu handek en tot bevordering van welvaart gevonden worden. Daarentægen bestaan er groote hinderpàlen, die nog lang het genot daarvan in den weg zullen staan. Als een voornaam beletsel, dat beschouwd kan worden tot de gesteldheid van het eiland te behooren, geef ik op, dat het vaarwater om het geheele eiland als bezaaid is met klippen en banken, en dat er in den westmoesson hevige stormen loeijen, waardoor de vaart voor raschepen altoos gevaarlijk zal wezen.

- Om zich een denkbeeld daarvan te kunnen maken voeg ik als bijlaag hierachter eene directie, om het eiland aan te doen en op de ree voor de rivier Tjoeroetjoep te ankeren, onlangs opgesteld door den eersten luitenant der koloniale marine Stolze, die door het gouvernement belast is, de kusten van Billiton op te nemen benevens eene kaart van het eiland,

Omtrent het planten- en dierenrijk was ik niet in staat, veel bijzonders te vernemen. De grond is bezaaid met allerlei kruiden en planten. Behalve wilde varkens en herten zijn er geen viervoetige dieren bekend. Noch wilde tijgers, noch andere verscheurende dieren verontrusten de bewoners; daarentegen zijn er slangen en vele insecten. Onder de laatsten heb ik een schorpioen gezien, die van den kop tot het einde der staart één voet lang was. Het varen op de ree over de onder water staande klippen levert het fraaiste gezigt, dat men zich kan voorstellen. De met mos en planten begroeide koraalklippen, de verschillende kleuren dezer steenen en der schelpen, die er zich op gezet hebben, vertoonen zich door de breking der lichtstralen in het helder water als sierlijke pronkstukken onder water aan het oog. Nog schooner was een stuk harde steen, dat van den grond afgestooten was; de zijde, die naar den grond gekeerd lag, was geheel tezaamgesteld uit kleine schelpjes, die de levendigste en schitterendste kleuren verspreidden. Deze toevallige ontdekking leerde mij op nieuw, dat de natuur, zelfs in hare onbekendste plaatsen, niet alleen doelmatig werkt, maar ook schoonheden bevat, die den mensch verrukken.

De geschiedenis van Billiton is ongeveer dezelfde als die der meeste eilanden in dezen archipel. De ware oorsprong der eerste bevolking is niet bekend; waarschijnlijk is die toevallig. De inwoners weten alleen, dat de Javaansche vorsten uit Madjapahit zendelingen tot hen gezonden hebben en dat zij door kracht van 
overreding en door hoop op voordeel zijn overgehaald, zich als onderworpen aan deze vorsten te beschouwen of hen ten minste te erkennen als humne bondgenooten en beschermers, aan wie zij dan ook wel eene weinig kostende hulde wilden bewijzen. ${ }^{1}$.

Nadat de vorsten van Madjapahit hun geducht aanzien en gevreesd vermogen verloren hadden en de vorsten van Palembang door de ontdekking der tinmijnen te Banka in vermogen en in magt waren toegenomen, kostten het dezen laatsten weinig moeite, Billiton' aan zich te onderwerpen, inzooverre als een volk dat over eene groote uitgebreidheid vruchtbaren grond, ontoegankelijke bosschen en eene ruime zee vol eilanden kan. beschikken, zich laat onderwerpen. Inderdaad ging de geheele onderwerping niet verder, dan dat de vorsten van Palembang het door de gezamenlijke inwoners gekozen hoofd bevestigden aan wien zij den titel van Dipati verleenden, en dat zij nu en dan eene kleine schatting vorderden, welke bestond uit producten van het eiland, als staafjes ijzer, rotting, matten, was en honig. Overigens hadden zij aldaar weinig of niets te zeggen.

Toen Banka in 1812 door den sultan van Palembang aan de Engelschen werd afgestaan en Billiton als eene onderhoorigheid van Banka in het contract van afstand genoemd was, trachtte de Engelsche resident van Banka, de majoor Court, Billiton onder zijn gezag te brengen. Hij zond zekeren Radja Akil met gewapende vaartuigen derwaarts, en reeds had de Dipati aangenomen, de bevelen van den Engelschen resident te zullen ontvangen, toen Radja Akil, die Billiton zelf wilde besturen, dezen Dipati op eene verradelijke wijze des nachts overviel en vermoordde. Na zijne terugkomst op Banka werd de Engelsche resident waarschijnlijk van het gedrag van Radja Akil onderrigt en heeft toen de zaken te Billiton gelaten, zoo als die waren. Toen het Nederlandsche gouvernement het eiland Billiton in bezit nam, is de zoon van den door Radja Akil vermoorden Dipati in diens plaats aangesteld onder den naam van Tjakra di Ningrat.

Dit zijn in het kort de groote omtrekken der geschiedenis van Billiton. Indien men ondergeschikte gebeurtenissen wenscht te weten, deze bestaan eensdeels in de oneenigheden, die nu en dan plaats vonden over de keuze tot hoofd van het eiland en die meestal eindigden met toe te geven aan

1 Ook in de bekende hjst der onderhoorigheden van Madjapahit komt Billiton als zoodanig voor. Tijdschr. voor Nederl. Indië, 1867, I, bl, 90. 
de magtigste partij, eu met feestvieringen, en ten anderen in invalien, die de bewouers van andere eilanden in sommige districten deden, ten einde vergoeding te verkrijgen voor vermeende of geleden verongelijking. Deze invallen werden òf bloedig en gevolgd door menschenroof, of in der minne bijgelegd door betaling van boete of door herstel van het geleden onregt. Eindelijk zouden er lange verhalen te doen zijn van oorlogen tegen vermetele zeeroovers, die zelfs niet gevreesd hebben, diep landwaarts in te dringen Doch al deze verhalen zijn zeer omslagtig, en daar men er geen nut uit trekken kan, omdat de waarheid der gebeurtenissen, die daarbij zouden plaats gehad hebben, twijfelachtig is, eu men daaruit noch karakters, noch daden zoude leeren kennen, die belangrijk kunnen geacht worden, heb ik vermeend, mij daarmede niet te moeten ophouden. In het algemeen kan men van alle inlandsche oorlogen zeggen, dat de bedreigers meestal de sterksten zijn, dat zij meer door schrik en vrees te verspreiden, dan wel door een krachtigen en welberaden aanval, trachten te overwinnen, dat de verdedigers zelden een geduchten tegenstand bieden, maar al zeer spoedig, door angst overmeesterd, vlugten of zich overgeven, en dat de overwonnenen zich hun lot getroosten en zich gedwee onderwerpen, aan hetgeen de overwinnaar vordert.

$\mathrm{Nu}$ zal ik overgaan tot dat, wat ik ontwaard heb omtrent de bewoners van het eiland Billiton, hun maatschappelijke inrigtingen en bedrijf. Men kan de bewoners van dit eiland gevoegelijk in twee soorten onderscheiden : het eene gedeelte bewoont en bebouwt den grond, terwijl het andere zich uitsluitend langs de kusten tusschen eilandjes en rotsen ophoudt, waar zij met vrouw en kinderen op kleine vaartuigen leven. De eersten hebben het voorkomen van gewone inlanders; zij zijn vernuftig en meer beschaafd, dan men zou verwachten, van de imboorlingen van een eiland, waar zich nimmer Europeanen vestigden. Zij kleeden zich zindelijk, hebben zeer goede huizen en spreken het Maleisch zeer zuiver; hun voorkomen teekent gezondheid, sterkte en vergenoegdheid. Het tweede gedeelte, dat onderscheiden wordt door den naam van Orang-Sekah en Orang-Lant, schijnt een geheel ander menschenras. Zij hebben een stout, gespierd en krachtig voor- komen; hunne gelaatstrekken zijn somber, hun hoofdhaar is ongekamd en verwilderd en hunne huid zwart. Zij dragen bijna geen kleederen. Het bijgeloof houdt hen aan hun verblijf op de zee gebonden; zij zeggen, dat de bliksem hen verpletteren zou, wan- 
neer zij zich op het land vestigden. Zij eten ook raauwe spijzen en verwerpen zelfs die niet, welke reeds aan bederf onderhevig zijn. Zij kennen geen godsdienst en erneren zich van de vischvangst en van het visschen van agar-agar en tripang, dat voor andere behoeften wordt verruild. Overigens zijn zij alleen door gemeenschappelijk belang aan enkele hoofden verbonden. Velen van hen worden zeeroovers, maar het is eene onwaarheid dat zij zich alleen door den zeeroof zouden onderhoudeu.

Het eiland Billiton is verdeeld in vijf districten ${ }^{1}$, die elk door rivieren van elkander gescheiden zijn. Zij heeten naar de hoofdrivieren: Tjoeroetjoep, Blantoe, Boeding, Siedjoe en Badauw. De tusschen de uitwatering der grensrivieren van elk district op zee verblijf houdende Orang-Sekah en Orang-Laut behooren onder het district, in wier wateren zij. zich ophouden. Elk district heeft een hoofd, dat Ingebei heet; alleen die van het district Tjoeroetjoep draagt den titel van Dipati en wordt beschouwd als hoofd van het geheele eiland.

In den loop dezer beschrijving heb ik, van deze hoofden sprekende, steeds gezegd, dat zij geacht, aangemerkt of beschouwd werden als hoofden, waarmede ik heb willen aanwijzen, dat men zich zeer vergissen zoude, indien men meende dat degenen, die hier als hoofden voorkomen, inderdaad eenig gezag konden uitoefenen. Al wat zij door hun invloed kunnen bewerken, geschiedt door raadgevingen en door pogingen, de zaken eenigzins te regelen, maar het is er verre van af, dat zij even als de regenten of hoofden van Java werkelijk gezag zouden uitoefenen. De tegenwoordige Dipati of hoofd van het eiland heeft er niets te bevelen; de overige Ingebei's beschouwen zich in het geheel niet aan hem ondergeschikt en het zal veel moeite kosten en alleen door beleid en eene verstandige handelwijze kunnen geschieden, dat de hoofden, het zoo noodzakelijk gezag verkrijgen. De eenige omstandigheid, waarin thans de hoofden als zoodanig werkzaam zijn, is het beslechten van geschillen tusschen de inlanders. Deze hooren zij en doen uitspraak, nadat zij met eenige oudsten hebben geraadpleegd. Indien hierbij steeds de regtvaardigheid en billijkheid werd in acht genomen, zouden zij zeer nuttig wezen en een grooten

1 Sedert 1856 is het eiland in zes districten verdeeld, waarbij zeer oneigenaardig de naam van het hoofddistrict in Tandjong Pandang veranderd is. Zie het, regeringsverslag over dat jaar. 
invloed kunnen verkrijgen, maar helaas, meestal wordt het regt verkocht, en dit makt dat ook zij geen vertrouwen hebben. Hij, die met het hoogste gezag op Billiton belast wordt, zal zich dus bijzonder verdienstelijk kunnen maken en grooten invloed kunnen verkrijgen, als hij zich bezig houdt met het hooren van de klagten en geschillen der inlan丸̧rs en dan met inachtneming hunner gebruiken en begrippen, gewijzigd naar onze kennis, regt spreekt met die onpartijdigheid en regtvaardigheid, die van een braaf en verstandig bestuurder kan worden verwacht. Bijna alleen op deze wijze kan mijns inziens het Nederlandsch gezag zoodanig gevestigd worden, dat het in al zijne uitgestrektheid op de bevolking zal kunnen werken. Dit is de grootste weldaad, die over het algemeen aan Indië, maar in het bijzonder aan Billiton kan worden geschonken, want de bewoners zuchten het meest onder het gemis eener goede regtsbedeeling. Zij hebbén zich genoeg van het gezag hunner hoofden onafhankelijk gemaakt, dan dat die hun veel leed zouden kunnen doen, maar het is onınogelijk, niet met anderen in aanraking te komen en daarmede geschillen te krijgen. Daar zij nu geen regt dan voor geld of groote opofferingen kunnen bekomen, is dit het voornaamste, dat hen drukt en beklagenswaardig maakt. Hem, die hierin voorziet, en dit kan onder het bestuur van het gouvernement geschieden, dien zullen zij gehoorzamen en eerbiedigen.

Overal in Indië, waar elk mensch zoo gemakkelijk aan zijn geringe behoeften kan voldoen, zal men zien, dat de bewoners daar, waar drukkende bepalingen, verkeerde inrigtingen of eene slechte regering bestaan, zich verspreiden en verwijderen van de personen en van de gelegenheid, waardoor zij kunnen gedrukt en gekweld worden, als dit niet door bijzondere omstandigheden al te moeilijk of onmogelijk wordt gemaakt. In een land, waar vruchtbare grond genoeg voor handen is, waar het volk nog niet door onderdrukking zoodanig verlaagd is, dat het onverschillig voor zijn lot geworden is, waar men bevindt, dat de inwoners de grootere veiligheid, en het genoegen, dat aanzienlijke en wel aangelegde dorpen aanbieden en verzekeren, vaarwel zeggen, om zich in kleine gehuchten of bij enkele huisgezinnen in de eenzaamheid neder te zetten, daar kan men ook verzekerd zijn, dat slechte -en drukkende bepalingen bestaan, waaraan de inwoners zich willen onttrekken, en dat deze zoo hard en kwellend moeteu zijn, dat z.j zick het 
ongezellige, het onveilige en al de aan eenzaamheid verbonden ongemakken liever laten welgevallen, dan zich aan de knevela. rijen hunner hoofden bloot te stellen. Dit bestaat op Billiton. De meeste inwoners hebben zich in kleine gehuchten of bij enkele huisgezinnen over het geheele eiland verspreid. Nu zal men gemakkelijk kunnen nagaan, dat de regering vooreerst nog weinig zal kunnen werken op zulk eene bevolking en dat menschen, gewoon op zich zelf te leven, een eigenzinnig karakter hebben verkregen en zoozeer aan de eens door hen opgevatte begrippen vasthouden, dat daarin niets dan na lang aanhouden en, nadat hun vertrouwen verkregen is, kan veranderd worden. Vooreerst valt er dus niets te doen, dan de inwoners te beschermen, door hun regt te laten wedervaren; deze bescherming zal hen aan ons verbinden, en daardoor eindelijk ter verbetering op hen kunnen gewerkt worden.

Eene bevolking, die zoo verspreid en als het ware zoo geheel op zich zelf leeft, houdt zich weinig aan maatschappelijke of godsdienstige instellingen. Buiten het huwelijk en de besnijdenis, hetgeen nog alleen onder de voornaamstén bestaat, hebben zijj niets, wat hen aan de maatschappij of de godsdienst verbindt. Op Billiton beschouwen de ouders zich, evenals te Palembang, in dien graad als de eigenaars hunner kinderen, dat zij die verkoopen of althans hunne dochters niet ten huwelijk geven, dan nadat daarvoor eene zekere som, Djoedjoer genaamd, betaald is. Daar deze overeenkomst, om een soort van wettigheid of kracht te verkrijgen, meestal voor de hoofden wordt aangegaan, ziju zij buitendien verpligt, deze te betalen; hierdoor wordt het trouwen zoo moeilijk en kostbaar, dat dit inderdaad een nadeeligen invloed op de uitbreiding der bevolking heeft. Van de Mohammedaansche godsdienst kennen zij niets meer dan de besnijdenis en weinige-andere uiterlijke plegtigheden. De godsdienst der Orang-Sekah en Orang-Laut is niet bekend; zij laten zich niet besnijden en eten varkensvleesch. Daardoor weet men, dat* zij geen Mohammedanen zijn ; waarschijnlijk vereeren zij een voorwerp der natuur. Hunne lijken begraven zij aan land. Hunne huwelijksplegtigheid bestaat hierin, dat zij bij stormachtig weder zoowel bruid als bruidegom in kleine versierde kano's plaatsen en die in zee duwen; zoodra de ranke schuitjes bij elkander komen of tegen elkander' stooten, stapt de bruidegom bij de bruid over en roeit met haar uaar den wal; dan zijn zij getrouwd. Ik meen, dat deze ervaren zeebewouers ongemerkt wel 
middelen zullen weten aan te wenden, die de kano's tot elkander doen komen, anders zoude het vrij lang kunnen duren, voordat zij bij elkander kwamen.

De hoofden der districten oefenen ook gezag, voor zoo verre dit gaan kan, over de Orang-Sekah en Orang-Laut. Indien nu deze hoofden zeerooverij willen plegen, halen zij daartoe eenige Orang-Sekah en Orang-Laut over. De moedigsten worden Panglima's genoemd, aan wie zij geven hetgeen tot de uitrusting noodig is. Eveneens verschaffen zij volk en provisiën aan de zeerooversvaartuigen, die van Lingga, Trengano en andere plaatsen, te Billiton komen. Van den geroofden buit ontvangen zij een ruim aandeel, zoodat de Orang-Sekah en Orang-Laut niet alleen de zeeroovers van Billiton ziju, maar wel degelijk ook de hoofden en andere aan land wonende inlanders, die eveneens bijdragen tot de uitrusting der rooversvaartuigen, en evenzeer, zoo niet nog meer, voor zeeroovers moeten gehouden worden: Waarschijnlijk zouden de Orang-Sekah en Orang-Laut niet vermogend genoeg zijn, om zeeroof te plegen zonder de ondersteuning van de hoofden en bewoners van het eiland. Deze verschuilen zich steeds achter de Orang-Sekah en Orang-Laut, die zij den naam van zeeroovers geven, terwijl die onbeschaafde, woeste en ruwe menschen meenen, dat zij een door de hoofden van het eiland als het ware geautoriseerd en gepermitteerd bedrijf uitoefenen. Men ziet hieruit, hoe deze slechtheden in elkander geweven zijn en elk der bedrijvers zich op zulk een voet wil stellen, dat hij niet gestraft kan worden of althans eene soort van verontschuldiging kan voorwenden, als de een of ander wraak wilde oefenen wegens hetgeen aan zijn landgenooten was overkomen. Hiervan bestaan voorbeelden; onder anderen rusten de inwoners van Banka, wanneer een hunner vaartuigen genomen is, dadelijk eene expeditie uit, om het verlorene terug te krijgen of vergoeding daarvoor te vragen. In zulk een geval komt het te pas, dat elk zich zoo goed mogelijk vrij kan pleiten. Maar men zal er ook uit zien, dat het tegengaan van den zeeroof op Billiton niet zoo moeilijk zal zijn als men wel gemeend heeft, wanneer er een Nederlandsch etablissement gevestigd blijft, waardoor men zelfs dien zal verminderen, welke van andere plaatsen met behulp der bewoners van Billiton bedreven wordt. Te meer zal men de mogelijkheid hiervan inzien, als men weet, dat ten onregte wel eens gezegd wordt, dat de bevolking van Billiton zich niet zoude kunuen erneren, als zij geen zeeroof 
bedreef. De Orang-Sekah en Orang-Jaut, kunnen evenals de overige bewoners van het "eiland zeer goed bestaan, de eersten van hetgeen de zee voortbrengt; en de laatsten van hetgeen zij uit den grond kunnen trekken. Het zal alleen zeer noodig zijn, dat men, wanneer er geen zeerooversvaartuigen meer kunnen komen, zorgt, dat er handel op Billiton wordt gedreven. Daartoe kan zeer veel bijdragen de reeds bepaalde vrijstelling van regten

- op den in- en uitvoer van goederen en het bestuur van een verstandig man, die de middelen, welke wij hieronder daartoe zullen voordragen, aanwendt.

Aangaande het aantal der bevolking, heb ik geen voldoende onderrigting kunnen bekomen. Dit is zeker dat Billiton in verhouding tot de uitgestrektheid eu vruchtbaarheid van den grond, en tot de kostbare voortbrengselen, die er te vinden zijn, zeer weinig bevolkt is. Men meent, dat er zes of zeven duizend menschen op het land zouden wonen, en dat de Orang-Sekah en Orang-Laut drie of vier duizend zielen zouden beloopen, zoodat de geheele bevolking negen à elf duizend zielen zoude bedragen. 1 De inwoners erneren zich door den landbouw, door het verzamelen van voortbrengselen uit de bosschen en door het graven en bewerken van ijzer, welk laatste van eene uitmuntende kwaliteit is, en waarvan zij zeer goede spijkers weten te maken.

De landbouw verkeert nog in zeer ruwen staat. Jaarlijks kappen zij eene zekere uitgebreidheid in het bosch om en laten het hout twee maauden liggen, om te droogen, waarna zij het verbranden en rijst op dezen grond zaaijen. Hiervoor dragen zij dan wel eenige zorg, maar behandelen en bewerken den grond niet genoegzaam, om er al de vruchten van te trekken, die bij meer arbeid daarvan zoude kunnen worden verkregen. Nadat de rijst van het veld is, en ook tusschen de rijst in, planten zij andere gewassen, als djagong, groenten, vruchten, katoen, suikerriet, ristjes of spaansche peper, enz., maar zij laten den uitslag meestal aan de goede natuur over. $\mathrm{Zij}$ leggen geen sawavelden of geregelde tuinen aan, waarop behoorlijk wordt acht geslagen, zooals de Javanen, maar vergenoegen zich met hetgeen hunne bijna onbearbeide velden afwerpen.

1 Volgens het regeringsverslag over 1863 - van dat over 1864 zijn de Bijlagen nog niet in het licht verschenen - bedraagt de oorspronkelijke bevolking van Billiton, behalve de Chineesche mijnwerkers en andere vreemde oosterlingen 12,000 zielen. 
Uit de bossschen verzamelen de inwoners was, kappen daar een soort van hout, dat voor hechten van krissen gebezigd wordt, en maken van rotting en biezen matten, die zeer fijn en fraai zijn. Ook halen zij het garoehout en al, wat zij voor het bouwen hunner huizen noodig hebben, uit de bosschen. De woningen worden niet van bamboesriet, maar van dunne boomen gebouwd, die zij als staken naast elkander plaatsen en van binnen met drooge bladeren digt maken. Waarschijnlijk tot afwering van slangen en insecten bouwen zij hunne huizen drie à vier voet boven den grond.

Het ijzererts wordt gevonden, somtijds even beneden de oppervlakte van den grond, in steenachtige stukken van meer of mindere grootte. Deze steenen, die vol poriën zijn, worden fijn gekapt en vervolgens wordt het erts gesmolten in een oven door een sterk vuur van houtskolen, dat gedurig met een blaasbalk wordt aangehouden. Het gesmolten ijzer loopt in een daartoe gemaakten bak en wordt daaruit geschept en in vormen gegoten, die één span lang en drie vingers breed zijn, somtijds in kleinere vormen, als het tot spijkers wordt verwerkt. Daarvan worden vier soorten te Billiton verkocht, als: $1^{\text {e }}$ soort, 7 duim lang, à $f 2$ de 100 stuks; 2 e soort, 5 duim lang, à $f 2$ de $200 ; 3$ e soort, $2 \frac{1}{2}$ duim lang, à $f 2$ de $300 ; 4$ e soort, $1 \frac{1}{2}$ duim lang, à $f 2$ de 400 . De staafjes worden verkocht bij het katje tegen $f$ 2. Dit ijzer is zeer hard.

Men beschuldigt de inwoners van Billiton, dat zij groote minnaars zijn van het dobbelspel, van hanengevechten en van het amfioen schuiven. $\mathrm{Ik}$ durf dit niet verdedigen, omdat dit verderfelijk kwaad genoegzaam door den geheelen archipel verspreid is, en daar het sterkst heerscht, waar goede maatschappelijke inrigtingen ontbreken, die andere en min verderfelijke vermaken in plaats van deze schadelijke aanmoedigen.

De bewoners van Billiton zijn zeer sterk van ligchaamsgestel; zij kunnen, wanneer dit noodig is, dagelijks 12 tot 14 uur te voet gaan over ongemakkelijke voetpaden De OrangSekah en Orang-Laut zijn bekwame duikers en kunnen verscheiden minuten onder water blijven; zij vangen ook visch met houten harpoenen en vervolgen die tot aan de kleine openingen in de rotsen en klippen, waar zij ze dooden. Men zegt, dat het wel gebeurd is, dat zij zich bij het overmeesteren van een klein vaartuig met een der opvarenden in zee geworpen en hem onder water gesmoord hebben. 
De handel op Billiton wordt met kleine inlandsche vaartuigen gedreven en zal nog lang op deze wijze moeten worden gevoerd, omdat er geen geregelde markten of stapelplaatsen zijn, waar een inlandsch handelaar, zonder veel nadeel te lijden, een. geruimen tijd kan blijven vertoeven. De opvarenden dezer vaartuigen hebben of aandeel in de lading òf zijn gehuurd voor de reis, onverschillig of die lang of kort duurt. Wanmeer zij op een plaats komen, laten zij dit aan de inwoners weten en wachten zoolang, totdat hunne lading verkocht of verruild is; intusschen beschouwen zij zich, alsof zij te huis zijn en trachten door vischvangst of ander bedrijf nog eenige voordeelen te verkrijgen.

De artikeleh, die door den handel met voordeel kunnen worden aangebragt zijn: opium, tabak, Europeesche sitsen, Javasche en Boegineesche lijnwaden, rijst, zout, Javasche suiker, lamp- en klapper olie, fijn en grof aardewerk en staal. De artikelen, welke daarentegen door den handel op Billiton verkregen worden, zijn: tripang, agar-agar, schildpad, gedroogde visch, vogelnestjes, garoehout, was, hars of ruwe dammer, ijzer, spijkers en andere voorwerpen van mindere waarde, als matjes, enz. enz.

Hiermede eindig ik mijne aanteekeningen over de gesteldheid, de voortbrengselen en de inwoners van Billiton en verzoek, dat met dit onvolmakkte genoegen mag worden genomen, en dat in gunstige verschooning zal komen de korte tijd van mijn verblijf aldaar en de bezigheden, die ik er te doen vond.

Thans moet ik overgaan tot mijne verrigtingen te Billiton en tot de voorstellen aan den kolonel en resident van Banka, omtrent hetgeen noodzakelijk moet worden gedaan.

Daar de hoofddirectie van financiën geen eisch van benoodigdheden voor Billiton ontvangen had en alleen in acht nam het dringend verzoek van den kommandant, hem uit Batavia van alles te voorzien, berekende zij naar haar beste weten, wat hij zoude kunnen noodig hebben, en zond verscheiden artikelen voor vivres, eenige andere goederen tot gerief der inwoners, en vijf-entwintig-duizend gulden in geld met het schip, dat mij naar Billiton bragt. Teveus magtigde de hoofddirecteur mij al, hetgeen te Billitọn niet noodig mogt zijn, naar Muntok op-Banka te zenden, werwaarts dit schip verder bestemd was. Kort voor mijn aankomst had de resident van Banka behalve eenige levensmiddelen nog twintig duizend 
gulden naar Billiton gezonden. Ik ging dus met den kommandant na, wat hij nog meer noodig had tot aan het einde van den westmoeson en liet het overige aan boord, om het te Muntok aan den resident af te leveren. Van het geld liet ik twaalf duizend gulden op Bilititon en deed een kist met dertien duizend gulden overschepen aan boord der koloniale korvet Koerier, omdat ik meende, dat het daar veiliger was dan aan boord van een partikulier schip; die som heb ik te Muntok aan den resident van Banka doen afgeven.

Het militaire departement had twaalf stukken, achtponders, zoo ik mịj niet vergis, naar Billiton gezonden, doch daar het niet mogelijk was, meer dan zes stukken in de twee halve cirkels van het fort te Tandjong-Simba te plaatsen; kwam ik met den kommandant overeen, niet meer dan deze te lossen en de overige naar Muntok te brengen. Naderhand heb ik van den resident van Banka berigt ontvangen, dat het schip Ennore Transit te Muntok aangekomen was en zijn lading gelost had, als ook dat de kist met dertien duizend gulden door den kommandant der. korvet Koerier aan den resident afgeleverd was.

Den beruchten zeeroover Radeen Alie vond ik aan den mond der rivier Tjoeroetjoep. Hij had zich vrijwillig onder het Nederlandsche gouvernement begeven, doch de civiele en militaire kommandant wist niet, hoe hij met hem zoude handelen, en had hem slechts voor eene waarde van, ik meen, tweehonderd gulden aan rijst en zout gegeven en dat wel voor een geheel jaar. Van dezen geringen bijstand kon Radeen Alie, 'die met zijn gezin en aanhang twee honderd menschen moet onderhouden, onmogelijk bestaan. Toen ik den kommandant deze bedenking maakte, moest ik tot mijn grootste verwondering vernemen, dat hij hem verdacht, nog zeeroover te zijn. De gedachte, dat iemand, in de magt en onder de bescherming van het gouvernement, nog zeeroof zoude plegen, ergerde mij zeer; en ik begreep, dat zonder uitstel hierin moest voorzien worden. Derhalve ontbood ik Radeen Alie met de hoofden zijner familie en met zijn gevolg bij mij en kwam na overleg met den kommandant, den Panembahan en den inlandschen majoor Tompel met hem overeen, dat hij zich met zijn gezin en aanhang zoude vestigen op Poeloe Lepar, een eiland tusschen Toebalie op Banka en Billiton, waar nij zoude waken tegen de zeeroovers, die van Lingga, Trengano en andere plaatsen daar vergaderen, en zich erneren zoude met de vangst van visch, tripang en agar-agar en met 
den landbouw en andere eerlijke middelen, terwijl ik tot te gemoetkoming in zijne behoeften en tot belooning der diensten, die hij tegen de zeeroovers zoude bewijzen, hem toelegde hon. derd gulden, een koijang of 30 pikols rijst en eene halve koijang zout in de maand en hem een certificaat gaf, dat het hem vergund werd, zich onder de voorschreven voorwaarden te Poeloe Lepar neder te zetten. Tevens werd de kommandant door mij geautoriseerd, Radeen Alie twee maanden voorschot te geven, en hem voorts maandelijks te betalen en te verstrekken, wat ik bepaald had, totdat hij hieromtrent nadere orders zoude ontvangen. Meer details van deze onderhandeling met Radeen Alie heb ik gegeven in mijn brief van 6 Augustus jongstleden aan den .kolonel en resident van Banka, waarnaar ik de vrijheid neem te verwijzen, daar die als bijlage hierachter is gevoegd. Omtrent dezen brief moet ik evenwel opmerken, dat mij door het onverwacht opgekomen vertrek naar Palembang maar weinige uren en dan nog onder gesprekken met heeren, die mij kwamen zien, waren gelaten om dien te schrijven en dat mij daarvan een slecht afschrift is gezonden, ten einde verschooning te erlangen voor de overhaasting, waarmede deze brief geschreven is. 1

De voet, waarop de Panembahan met den kommandant stond, was zoo gespannen, en zelfs vijandig, dat zij onmogelijk langer

1 Uit van Sevenhovens brief aan den resident van Banka blijkt nog over deze onderhandelingen, dat Radeen Ali zelf aan den kommissaris een eerlijk middel van bestaan verzocht, daar'hij met zijn groot gezin ęn gevolg onmogelijk van den hem door den kommandant gegeven onderstand leven kon. Van Sevenhoven verwees hem naar den majoor Tompel, om met dezen te overleggen, wat voor hem in het vervolg het wenschelijkst was. Daardoor kwam Radeen Ali tot het verzoek, zich op Poeloe-Lepar te vestigen, waar zich destijds alleen eenige Orang-Laut ophielden en dat voldoende hulpmiddelen voor zijn levensonderhoud aanbood. Van Sevenhoven begreep zeer goed, dat hij op die wijze Radeen Ali in staat kon stellen, zijn oud bedrijf te hervatten, maar er moest raad geschaft worden. Eerst dacht hij er over, hem naar Muntok mede te nemen, maar indien dit Radeen Ali niet aanstond, kon deze zich daaraan onttrekken, door ziekte voor te wenden, terwijl het evenmin aanging, iemand gevangen te nemen, die zich rrijwillig onder de bescherming van het gouvernement had gesteld. Op grond dezer overwegingen besloot van Sevenhoven het verzoek toe te staan. Zonder omwegen gaf hij echter aan Radeen-Ali te kennen, zeer goed in te zien, dat hij hem door het verblijf op PoeloeLepar de gelegenheid verschafte, op nieuw zeeroof te plegen, maar dat de edelmoedigheid der Nederlandsche regering zoo groot was, dat zij liever eerst de proef wilde wagen, of hij van het kwaad terug te brengen was, 
bijeen konden blijven, daar het zelfs te vreezen was, dat zij elkander eindelijk openlijk zouden beleedigen. Ik oordeelde het dus raadzaam, den Panembahan naar Muntok te doen vertrekkeu, waar hij een dag na mij is aangekomen; ik meende te meer daartoe de vrijheid te hebben, daar ik bekend was met de resolutie van zijne excellentie den Gouverneur-Generaal in rade van den 15 April jl., no. 4, warbij dea resident van Banka was aangeschreven, den Panembahan uit Billiton op te roepen.

Voorts heb ik den kommandant gemagtigd, eenige koelies voor ziju magazijn en voor de infirmerie in dienst te nemen, dewijl ik dit hoogst noodig beschouwde en heb hem gezegd, dat hij deswegens, eene voordragt zoude doen aan den resident van Banka, wien ik daarover zoude spreken.

De voorstelleu die ik meende aan den resident van Banka te moeten doen, om zoo spoedig mogelijk in de bestaande ongeregeldheden te Billiton te voorzien en de zaken in eene goede orde te brengen, zijn vervat in mijne zoo even vermelde missive, waarnaar $i k$ mede de vrijheid neem te verwijzen, om dit reeds te groot rapport niet nog meer te verlengen. Deze voorstellen zijn: 10. den civielen en militairen kommandant van Billiton op te roepen, zoo tot herstel van zijne gezondheid, als om zijne administratie in orde te brengen;

2o. mede van Billiton te doen opkomen den assistent Wetering Buis;

3". den heer Bierschill, reeds benoemd tot inspecteur der tinmijnen te Banka, naar Billiton te zenden, om aldaar het civiel gezag te voeren;

dan hem reeds nu te straffen. Hierbij merkte van Sevenhoven op, dat Radeen Ali thans geheel in zijne magt was en verzekerde hem eindelijk, dat het gouvernement, wanneer hij ooit van het nu in hem gestelde vertrouwen misbruik maken mogt, niet rusten zou, voordat hij, Radeen Ali, met zijn geheele geslacht en aanhang tot den laatsten man was uitgeroeid. In het bijzijn van zijne familie, den majoor Tompel en andere inlandsche hoofden legde Radeen Ali den eed van trouw aan het Nederlandsch gezag af en beloofde, zich voortaan geheel van den zeeroof te onthouden en niet te dulden, dat die op Lepar door anderen werd uitgeoefend. Derwaarts verzelde hem de zoon van Tompel met den rang van inlandsch kapitein, om op zijne handelingen toezigt te houden.

In hoever Radeen Ali beantwoord heeft aan de verwachtingen van van Sevenhoren, is mij niet bekend. Zijn naam komt niet voor in hetgeen de heer Cornets de Groot over de geschiedenis van den zeeroof heeft bijeenverzameld. 
40. een officier als militair kommandant op Billiton te plaatsen;

50. den Panenbahan Sarief Mohaned met den heer Bierschill terug te zenden.

en $6^{\circ}$. dadelijk op Billiton maatregelen te nemen door het omkappen der boomen, enz., dat het fort naar Tandjong Goenong aan den mond der rivier Tjoeroetjoep verlegd worde. Op deze verrigtingen hoop ik de goedkeuring van het gouvernement te zullen verkrijgen, die ik bij deze eerbiedig verzoek onder verklaring, dat ik na rijp beraad heb gehandeld, en dat ik het als mijn pligt beschouwde, zoodanig te handelen en niet de zaken haar gang te laten gaan, toen mij gebleken was, dat die zonder groot gevaar niet langer in den staat, waarin ik ze

1 Alleen over deze herbenoeming van den Panembahan bevat van Sevenhovens brief aan den resident van Banka nadere bijzonderheden. De la Fontaine was toch door de klagten van den kommandant over den Panembaham bewogen, den laatstgenoemde in het ongelijk te stellen en had deswegens aan de Indische regering diens ontslag voorgedragen. Van Sevenhoven trachtte nu in zijn schrijven den resident over te halen, op dit gevoelen terug te komen. Want al erkende ook hij, dat de Panembahan zich onbehoorlijk jegens den kommandant gedragen had, ten deele uit overmoed wegens de groote protectie, die hij te Batavia genoot, iets dat op alle inlanders en vooral op Palembangsche grooten nadeelig werkt, het onverstand van den kommandant was toc' de hoofdoorzaak zijner oneenigheid met den Panembahan. Bovendien had van Sevenhoven den laatste reeds verklaard, hoezeer hij de ontevredenheid van den gouverneur-generaal had opgewekt, omdat hij in geenen deele had beantwoord aan het in hem gestelde vertrouwen, noch zijne beloften gestand had gedaan. De Panembahan betuigde toen zijn leedwezen met het voorgevallene en verzocht dringend, in weerwil van zijn hoogen leeftijd tot behoud van zijn goeden naam op nieuw naar Billiton gezonden te worden, om daar te herstellen, wat verzuimd en bedorven was. Van Sevenhoven was nu van oordeel, dat er op Billiton zonder een inlander van aanzien weinig goeds tot stand zoude komen, dat er, daar alle inlanders met hetzelfde zuurdeesem doortrokken zijn, van een ander niet veel beters te wachten was, terwijl de Panembahan èn om de ontevredenheid van den gouverneur-generaal, èn omdat zijn grootste protecteur niet meer in Indië was, thans al zijn invloed, kennis en verstand, zelfs bij inlanders van zijn rang niet algemeen, zoude aanwenden, om het gebeurde uit te wisschen. Indien de resident in deze beschouwingen treden kon, moest hij aan den Panembahan de vijf vaartuigen laten, die deze voor rekening van het gouvernement in dienst had, terwijl het overige inlandsche bestuur te Billiton op den bestaanden voet blijven moest, totdat Bierschill na een verblijf van eenige maanden kon hebben nagegaan, in hoever daarop te bezuinigen viel.

De protecteur van den Panembahan, op wien van Sevenhoven telkens doelt, was mijns inziens de raad van Indië Muntinghe, die in 1818 kommissaris in Palembang was en die in de laatste dagen van 1822 met verlof naar Europa ging. 
gevonden had, konden blijven, vertrouwende, dat zijne excellentie de Gouverneur-Generaal, die mij gelast had, naar Billiton te vertrekken, mijne goede oogmerken zoude in aanmerking nemen en al ware het ook, dat ik mij in mijne maatregelen mogt vergist hebben, mij dit niet ten kwade zoude duiden.

Zoo ben ik genaderd tot het laatste gedeelte van dit rapport, namelijk tot de mededeeling, wat volgens mijne geringe inzigten in het vervolg ten aanzien van Billiton dient te worden bepaald, om het op de minst kostbare wijze dienstbaar te maken aan de belangen van het Nederlandsch gouvernement. Niet zonder bedeesdheid waag ik het mijne denkbeelden over dit onderwerp onder de geëerde aandacht van het verlichte gouvernement te brengen en zeker zoude ik deze stoutheid niet nemen, als ik niet mogt vertrouwen op de toegevendheid van zijne excellentie den Gouverneur-Generaal en op de mogelijkheid, dat het mij, die ter plaatse geweest is, misschien kan gelukken iets te zeggen dat, zoo al niet volkomen goed, althans anderen tot het bedenken van betere bepalingen kan brengen, waardoor ik ten minste van mijnen kant iets zal bijdragen, om die te verkrijgen.

Alvorens tot de algemeene bepalingen te komen, meen ik vooraf het gouvernement eerbiedig te mogen voorstellen de volgende bijzondere maatregelen te nemen:

10. dat de civiele en militaire kommandant eervol uit zijne betrekking worde ontslagen, eervol, uit aanmerking dat de man veel werk, veel verdriet en moeijelijkheden heeft gehad en naar zijn beste inzigt met een goeden wil, om het oogmérk van zijn taak te bereiken, heeft gehandeld, terwijl de verkeerdheden, die hij gedaan heeft, alleen moeten worden toegeschreven aan zijne ongeschiktheid, om met den inlander om te gaan, en aan zijne onbekwaamheid voor den post, die hem was opgedragen; 20. dat mogen worden gevalideerd al de uitgaven, die de kommandant heeft gedaan, zoo voor transportkosten, koelieloonen, als tot het oprigten van een fort, enz. enz. alsmede de voorschotten aan den Dipati en anderen op Billiton;

30 . dat eveneens worden gevalideerd de verstrekkingen die door hem zijn gedaan in rijst en zout voor arbeiders en de afgave van deze en andere artikelen, waarvoor men hem tripang, agaragar, spijkers en andere voortbrengselen in ruiling beloofd had en dat deze voorschotten en het bedrag der afgegeven artikelen als een schuld aan het gouvernement mogen blijven voortloopen, 
om daardoor degenen, die nog geld of goederen schuldig zijn, onder naauwer of sterker verpligtingen te kunnen houden, ex in de hoop, dat daarvan later nog eenige afbataling zal geschieden. Eindelijk dat vergunning worde verleend, om in de boeken van Billiton als verloren af te schrijven al hetgeen bevonden zal worden in de magazijnen te kort te komen, - alzoo dat verloren is geraakt door te min gewigt op de nitgeleverde lading, door diefstallen bij het brengen van boord naar de magazijnen, door diefstallen in de magazijnen, door verzuim van goede aanteekeningen en door bederf, van welke omstandigheden niet behoorlijk proces-verbaal is gehouden.

Ik ben gedreven tot het doen dezer eerbiedige voorstellen, omdat de kommandant zonder deze finale en gunstige afdoening groote moeite zoude hebben, zich te kunnen verantwoorden en omdat, indien deze zaken voort bleven loopen, het voor een volgend gezagvoerder onaangenaam en verdrietig zoude zijn daaromtrent informatiën te moeten geven, waardoor hij welligt den tijd, dien hij noodig heeft, om "nuttiger zaken te doen, daaraan zoude moeten opofferen, terwijl er toch geen mogelijkheid bestaat, terug te krïgen hetgeen besteed is en hetgeen verloren moet worden geacht, en ik mij overtuigd houd van de eerlijkheid van den kommandant, die ook dit eev en ander met de beste inzigten heeft uitgegeven en buiten zijn schuld is kwijt geraakt;

3o. dat de inspecteur der tinmijnen te Banka Bierschill mag. worden benoemd tot assistent-resident van Billiton, en dat hem provisioneel blijve toegevoegd de Panembahan Sarief Mohamed.

$\mathrm{Nu}$ overgaande tot de algemeene bepalingen voor. Billiton meen $\mathrm{ik}$ dat dient te worden vastgesteld:

I. dat het eiland Billiton zal blijven eene onderhoorigheid van de residentie Banka en van daar voorzien zal worden van alle behoeften, hetgeen veel beter kan geschieden dan regtstreeks van Batavia of Java.

II. dat het Nederlandsche etablissement zal worden opgerigt te Tandjong Goenong, gelegen aan den mond der rivier Tjoeroetjoep en op de westkust van het eiland Billiton en dat daar een fort zal worden aangelegd.

Indien de vraag mogt ontstaan, of deze gelegenheid de beste van het eiland is en of er geene andere geschikte platsen zijn, die hetzij wegens eene goede reede of wegens andere locale omstandigheden voordeeliger kunnen worden geacht, meen ik daartegen in consideratie te mogen geven; vooreerst al de voordeelen, 
die hierboven zijn opgegeven; ten anderen dat deze plaats tegenover Toebalie op het 'eiland Banka ligt, dat hier sedert zeer langen tijd het hoofddistrict is geweest, terwijl men veronderstellen mag, dat de bevolking de beste en geschiktste plaats daarvoor zal gekozen hebben, en eindelijk dat allen, die ik gevraagd heb, of er nog andere beter gelegen plaatsen op Billiton waren, mij gezegd hebben, die niet te kennen, daar voor alle rivieren klippen en banken liggen, terwijl de Tjoeroetjoep voor de grootste rivier gehouden wordt.

III. dat het etablissement zal bestaan uit een assistent-resident, die in naam van het Nederlandsche gouvernement het gezag over het eiland zal voeren en aan wien worden toegevoegd twee klerken, eenige inlandsche mandoors en koelies en uit eene militaire bezetting van vijftig man, benevens een kanonneerboot of twee pinassen en twee of drie kleinere inlandsch gewapende vaartuigen.

IV. dat in den omtrek van het etablissement zullen moeten worden opgerigt een of meer kampongs' of dorpen, waartoe vreemdelingen dienen te worden aangemoedigd. Reeds hadden zich eenige huisgezinnen van Trengano, Lingga, en andere plaatsen aldaar ter nedergezet; ook zouden de residenten van buiten-etablissementen kunnen worden aangeschreven, daartoe menschen aan te moedigen. Vooreerst zoude elk, die zich daar nederzet, vrij van alle belastingen kunnen worden gelaten, en hem het vrije gebruik vergund moeten worden van alles, wat Billiton oplevert.

Het nut van deze dorpen beschouw ik als zeer groot, dewijl het te verwachten is, dat daar de stapelplaats voor den handel op het geheele eiland zal komen, omdat ieder daar niet alleen zijne waren veilig zal kunnen verkoopen en beheeren, maar ook eene dadelijke bescherining tegen bedrog en geweld kan verwachten. De inwoners van Billiton zullen evenals de Orang Sekah en Orang Laut, zoodra het bekend is dat de handelsvaartuigen zich daar bevinden, met hunne goederen derwaarts trekken, en zoo zal hun eene goede gelegenheid worden verschaft, deze op de voordeeligste wijze van de hand te zetten.

Zoolang de handelaren van Java en elders zich nog niet veilig beschouwen om op Billiton te varen, zal het noodig zijn, buitengewone middelen in het werk te stellen, om vooreerst althans aan de inwoners gelegenheid te geven, hunne waren vau de hand te zetten en in hunne behoeften te voorzien. Tot heden werd die gelegenheid meestal verschaft door zeeroovers, of door 
volk, dat met hen in verband staat. Bij mij is een denkbeeld opgeknmen, waardoor ik meen, dat hierin zal kunnen worden voorzien, namelijk het verpachten van sommige artikelen, zoo als de inzameling van tripang, agar-agar en vogelnestjes, vooreerst niet met het oogmerk, om daarvan voordeel te trekken maar om aan de Orang-Sekah en Orang-Laut gelegenheid te geven de voorwerpen, die zij inzamelen, van de hand te zetten, en ook om hen door pachters onder de verpligting te brengen, deze te moeten verzamelen. Deze pachters zouden Chineezen of daarmede gelijkgestelde inlanders moeten zijn. Dit soort van menschen verstaat de kunst, alle hulpbronnen op te sporen en de inlanders door voorschotten en allerlei middelen aan het werk. te houden. Hoe schadelijk de Chineezen in sommige gedeelten van Java ook mogen zijn, houd ik hen voor het beste, zoo niet het eenige volk, dat in staat is, uit een land, waar de bevolking nog zeer ruw is, de verborgen hulpbronnen voor den dag te brengen en het als het ware voor te bereiden, om naderhand meer geregelde en met de belangen van de bevolking meer overeenkomende bepalingen te kunnen invoeren. Men zal onder de tegenwoordige omstandigheden geen vermogende Chineezen kunnen vinden, die dit zullen ondernemen, en daarom zoude het noodig zijn, dat het gouvernement in zijne magazijnen een ruimen voorraad voorhanden had van artikelen geschikt voor den handel op Billiton, en dat het den pachter of pachters vergund werd daaruit op krediet te ontvangen onder zoodanige bepalingen en zekerheid, als in 's lands belang noodig werd geoordeeld. Men zal hiertegen kunnen irbrengen, dat de bevolking dan bloot gesteld zoude worden aan knevelarij en bedrog dezer pachters; ik kan dit niet ontkennen, maar mag daartegen in bedenking geven, dat men den prijs zoo van de goederen, die worden verkocht, als van die artikelen, die van de inwoners worden gekocht of in ruil aangenomen, zoude kunnen bepalen; dat een volk als de Billitonneezen zich niet zoo geheel gemakkelijk laat knevelen of bedriegen, dewijl zij sedert lang gewoon zijn, met slecht volk te handelen en eindelijk dat men van den assistent-resident moet verwachten, dat hij zooveel doenlijk hiertegen zal waken.

Indien men deze middelen als ontoereikend, te gevaarlijk, of ondoelmatig mogt beschouwen, zal het vooreerst althans noodig zijn, dat van wege het gouvernement een soort van ruilhandel wordt gedreven met de inwoners en dat de assistent-resident gemagtigd wordt, de ingeruilde artikelen te Billiton te verkoopen, 
dewijl er, als deze artikelen naar Banka moeten worden gezonden, geen handel te Billiton kan komen. Deze ruilhandel zal veel moeilijkheden geven en het zal noodig wezen, dat aan den assistent-resident iemand toegevoegd wordt, die kennis heeft van de artikelen, welke hem in ruil worden gegeven, omdat het te vreezen is, dat hij anders met slecht en bedorven goed zal worden bedrogen. De assistent-resident moet dan ook wel worden onderrigt, dat het doel van dezen ruilhandel niet is, voordeel aan het gouvernement te bezorgen, maar alleen de inboorlingen te gerieven, en dat hij alleen zorgen moet, dat het gouvernement zoo veel mogelijk buiten schade blijft; dat hij ook geenszins den handel van anderen moet tegengaan of beletten. Indien na een of twee jaren de hulpbronnen van Billiton bekend zijn, zouden er belastingen kunnen worden geheven, om de kosten van het etablissement goed te maken.

V. dat het besluit van het gouvernement van 7 December 1821 no. 10, waarbij de handel op Billiton is opengesteld en vrij verklaard wordt van regten zoo op den in- als uitvoer, blijft bestaan en dat tevens de invoer van zout uit Java, evenals die op Borneo en Palembang, wordt vrij gesteld onder genot van eene premie van f 15 voor elke koyang, die van Java zal zijn aangebragt.

Omtrent de tin, die op Billiton nog in de aarde is, zoude ik van oordeel zijn, dat men het aan den tijd en de ontwikkeling der nijverheid moet overlaten, wanneer er mijnen zullen worden ontgonnen. ${ }^{1}$ Op Banka kunnen nog honderden Chineezen meer, dan er thans zijn, met het ontginnen van tinmijnen worden bezig gehouden. Indien er nu meer Chineezen te bekomen zijn, om in de timmijnen te arbeiden, dan vermeen ik, dat het veel raadzamer is, dat men die op Banka in het werk stelt dan op Billiton, omdat op Banka reeds geregelde inrigtingen zijn, die dus minder kosten vereischen dan te Billiton, waar alles van nieuws af zoude moeten worden begonnen. Zoo lang er dus nog gebrek aan handen te Banka is, dient men aldaar het delven van tinerts uit te breiden. Is er op Banka geen volk meer met

1 Zonderling is het, dat Dr. Croockewit in zijn bekend betoog tegen het bestaan van tin op Billiton (Natuurk. Tijdschr., III. bl. 396) alleen deze eerste zinsnede aanhaalt en het overige weglaat, waaruit ten duidelijkste blijkt, dat van Sevenhoven hoegenaamd niet betwijfelde, of Biliton tin bevat, maar dat hij het alleen in den toenmaligen stand van zaken niet raadzaam oordeelde, dit van gouvernementswege te doen delven. 
nut te gebruiken, dan eerst kan het belangrijk en voordeelig worden de tinmijnen op Billiton te openen. Daar de inboorlingen het ijzererts smelten en bewerken, is het wel mogelijk, dat zij op te wekken zijn, om ook de tinmijnen te bearbeiden, indien deze arbeid, niet zoo als men zegt, te zwaar voor de inlanders is.

Over het goud, dat te Billiton zou worden gevonden, zal ik niets zeggen. Die weet, hoeveel arbeid het kost, dit te zoeken, en welke inrigtingen daarvoor op Borneo zijn, zal mij toegeven, dat er vooreerst nog niets kan worden ondernomen, om daarvan voordeel te trekken. Het zal dus het beste zijn, dit nog maar in den schoot der aarde te laten rusten. 1

De bewerking en smelting van het ijzer is nog zeer onvol: komen. Mogelijk zouden kundige lieden de kwaliteit door eene andere bewerking kunnen verbeteren, maar hiervoor moet ook eene goede gelegenheid worden afgewacht. Evenwel zoude men kunnen onderzoeken, of de spijkers, die te Billiton worden gemaakt en voor zeer goed worden gehouden, door het gouvernement te gebruiken zijn; in welk geval men de spijkers voor het gouvernement kon laten vervaardigen, om daardoor veel menschen aan den arbeid te krijgen, die nu het maken van·spijkers als eeu bijwerk beschouwen en er zich alleen mede bezig houden, wanneer die gevraagd worden.

Hiermede meen ik al, wat maar eenigzins van belang kan worden geacht ten aanzien van Billiton en van mịne kommissie, te hebben afgehandeld. Ik hoop, dat ik zoo gelukkig zal geweest zijn, eenigzins althans het oogmerk, waartoe ik gezonden was, te hebben mogen bereiken, en verzoek gunstige verschooning voor het gebrekkige van mijn arbeid.

1 De ingenieur de Groot maakt geen gewag van goud op Billiton, maar wel van koper, dat er echter slechts in geringe hoeveelheid gevonden wordt. (Natuurk. Tijdschr. III. bl. 138.) 